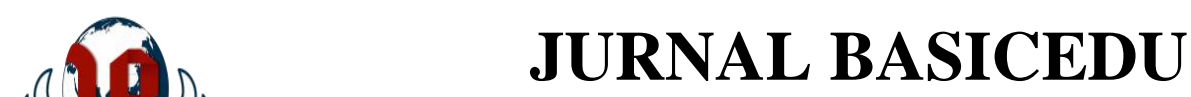

Volume 5 Nomor 3 Tahun 2021 Halaman 1584 - 1592

Research \& Learning in Elementary Education

https://jbasic.org/index.php/basicedu

\title{
Pengembangan Media Pembelajaran Tembang Macapat Berbasis Android Bagi Mahasiswa PGSD UPGRIS
}

\author{
Prasena Arisyanto $^{1 \bowtie}$, Singgih Adhi Prasetyo ${ }^{2}$, Mei Fita Asri Untari ${ }^{3}$, Riris Setyo Sundari ${ }^{4}$ \\ Universitas PGRI Semarang, Indonesia ${ }^{1,2,3,4}$ \\ E-mail: prasenaarisyanto@upgris.ac.id ${ }^{1}$, singgihadhi@upgris.ac.id ${ }^{2}$, meifitaasri@upgris.ac.id $^{3}$, \\ ririssetyo@upgris.ac.id ${ }^{4}$
}

\begin{abstract}
Abstrak
Pandemi covid-19 telah memberikan pengaruh pada bidang pendidikan. Proses belajar mengajar harus dilakukan secara online dengan segala keterbatasannya. Namun pandemi bukan menjadi alasan untuk melakukan pembelajaran secara seadanya. Perlu usaha yang lebih dalam memaksimalkan proses pembelajaran. Salah satunya adalah pengembangan media pembelajaran tembang macapat yang berbasis android. Pengembangan media pembelajaran tembang macapat bertujuan untuk memperlancar proses pembelajaran, mengatasi keterbatasan ruang dan waktu, pewarisan budaya, dan pendidikan karakter. Pada penelitian ini dikembangkan draf awal media pembelajaran macapat yang diberi nama "menang maca". Pengembangan media ini didasari oleh munculnya kendala dalam proses perkuliahan pendidikan seni musik secara online. Pandemi covid-19 telah membuat peneliti belajar banyak hal baru dan berusaha lebih kreatif. Secara tidak langsung pandemi covid-19 juga telah memberikan dampak positif bagi dunia pendidikan.
\end{abstract}

Kata Kunci: Aplikasi Menang Maca, Media Pembelajaran Macapat, Belajar Online, Pandemi Covid-19.

\begin{abstract}
The Covid-19 pandemic has had an impact on the education sector. The teaching and learning process must be carried out online with all its limitations. But a pandemic is not an excuse for improper learning. It takes more effort to maximize the learning process. One of them is the development of learning media for Macapat songs based on android. The development of learning media for tembang macapat aims to expedite the learning process, overcome the limitations of time and space, cultural inheritance, and character education. In this study, an initial draft of the Macapat learning media was developed which was named "Menang Maca". This media development is based on the emergence of obstacles in the process of online music education lectures. The Covid-19 pandemic has made researchers learn many new things and try to be more creative. Indirectly, the Covid-19 pandemic has also had a positive impact on the world of education.
\end{abstract}

Keywords: Menang Maca Application, Macapat Learning Media, Online Learning, The Covid-19 Pandemic.

Copyright (c) 2021 Prasena Arisyanto, Singgih Adhi Prasetyo Mei Fita Asri Untari, Riris Setyo Sundari

Corresponding author :

Email : prasenaarisyanto@upgris.ac.id

DOI : https://doi.org/10.31004/basicedu.v5i3.945

ISSN 2580-3735 (Media Cetak)

ISSN 2580-1147 (Media Online) 
1585 Pengembangan Media Pembelajaran Tembang Macapat Berbasis Android Bagi Mahasiswa PGSD UPGRIS - Prasena Arisyanto, Singgih Adhi Prasetyo, Mei Fita Asri Untari, Riris Setyo Sundari

DOI : https://doi.org/10.31004/basicedu.v5i3.945

\section{PENDAHULUAN}

Salah satu kebijakan new normal yang diterapkan di Indonesia ada pada bidang pendidikan, yaitu kebijakan belajar dari rumah, belajar jarak jauh, belajar online. Sekolah untuk sementara dilarang melakukan pembelajaran secara klasikal atau tatap muka seperti biasanya. Namun proses pembelajaran harus terus berjalan, maka diambil kebijakan agar pembelajaran terus berlangsung dalam kondisi apapun. Sekolah yang diperbolehkan menyelenggarakan kelas tatap muka adalah sekolah yang berada pada zona hijau, itupun juga tetap harus melaksanakan protokol kesehatan yang sudah ditetapkan oleh pemerintah.

Penelitian (Pratiwi \& Wahyudi, 2021) menyebutkan bahwa pada pembelajaran daring di sekolah dasar, terdapat banyak kendala antara lain keterbatasan fasilitas yang dimiliki, sulitnya akses internet, dan borosnya kuota internet. Maka untuk mengatasi permasalahan tersebut dikembangkan bahan ajar tematik berbasis website untuk peserta didik di sekolah dasar yang dapat diakses dimana saja, mempunyai biaya operasional yang terjangkau, dan dapat meningkatkan kemandirian dalam belajar. Kendala yang sama juga terjadi pada tingkat universitas, perkuliahan sepertinya dapat berlangsung dengan mudah dan lancar dengan adanya smartphone, namun ternyata ada kendala besar yang menghalangi proses perkuliahan, yaitu jaringan internet dan kemampuan membeli kuota internet. Jaringan internet belum terbangun secara merata, masih banyak daerah yang kesulitan akses internet terutama di daerah pedesaan. Kemudian kemampuan untuk membeli kuota internet juga menjadi masalah karena proses perkuliahan daring menghabiskan banyak kuota internet. Pengeluaran bertambah, sedangkan pada masa pandemi ini ekonomi sedang sulit sehingga menambah beban lebih banyak dibanding pada masa normal.

Masalah yang muncul dalam proses perkuliahan juga disampaikan oleh (Syamsurijal \& Sarwan, 2021) yang dalam penelitiannya menyampaikan bahwa pembelajaran daring telah memicu kondisi psikologis mahasiswa PGSD Universitas Muhammadiyah Buton merasa stres, resah, cemas, bosan, dan pusing. Berdasarkan penelitian tersebut kemudian disarankan agar para pendidik bisa memilih metode dan sarana pembelajaran yang tepat untuk meminimalisir permasalahan psikologi mahasiswa yang muncul akibat dari pembelajaran daring.

Berbagai kendala tersebut tidak bisa dihindari karena perkuliahan harus terus berlangsung. Perkuliahan daring menjadi alternatif yang paling baik meskipun banyak masalah. Pemanfaatan internet tidak bisa dihentikan, yang bisa dilakukan untuk menanggulangi masalah jaringan adalah dengan mencari alternatif proses perkuliahan daring. Berbagai hal seperti membatasi video call, membuat modul dan media offline yang bisa digunakan dalam waktu yang cukup lama dirasa bisa menjadi solusi jangka pendek dalam perkuliahan daring, sampai bisa melaksanakan perkuliahan secara normal kembali.

Salah satu usaha yang bisa dilakukan yaitu membuat media pembelajaran yang juga bisa digunakan secara offline atau tanpa jaringan internet. Pada penelitian ini akan dibuat produk berupa media pembelajaran berbasis android atau aplikasi yang bisa dijalankan pada smartphone. Hanya dengan sekali mengunduh atau mengkopi file program, maka bisa digunakan di smartphone tanpa jaringan internet. Produk dalam penelitian ini ditujukan pada pembelajaran macapat di sekolah dasar, namun pada penelitian ini dilakukan uji coba draf produk pada mahasiswa PGSD UPGRIS sebagai calon guru di sekolah dasar.

Penelitian (Widodo, 2010) mengenai lelagon dolanan anak dan pendidikan karakter, telah berhasil menciptakan lelagon dolanan anak yang sesuai dengan perkembangan anak usia SD. Penelitian Widodo dilatarbelakangi langkanya media pembelajaran lelagon dolanan berlaras slendro pelog bagi anak yang sesuai dengan perkembangan zaman, kontektual, dan memuat nilai-nilai pendidikan bagi anak. media yang ada yaitu tidak berlaras slendro pelog, tetapi bernada diatonis. Kemudian catatan mengenai lelagon dolanan anak masih berupa tulisan tangan yang atau ketikan lama, yang hanya dimiliki oleh orang-orang tertentu saja.

Penelitian Widodo menjadi dasar konsep bagi penelitian ini. Tembang macapat memang banyak memiliki variasi syair, tetapi diperlukan tembang macapat yang sesuai dengan perkembangan zaman, sesuai 
dengan kebutuhan guru di sekolah, dan mudah dipahami. Isi tembang macapat bisa menjadi sumber pendidikan yang bisa membangun karakter bangsa (Prihantono, 2019). Oleh karena itu pada penelitian ini akan disusun media pembelajaran tembang macapat, dengan syair tembang yang disesuaikan dengan kebutuhan pembelajaran di sekolah dasar.

Tembang macapat merupakan produk budaya Jawa yang keberadaannya sampai saat ini masih hidup dan berkembang di Nusantara khususnya pulau Jawa. Meskipun perkembangannya tidak sepesat teknologi namun tembang macapat masih dihadirkan dalam kehidupan masyarakat terkait fungsi-fungsi tertentu seperti upacara kelahiran, perkawinan, maupun mengucap syukur kepada Tuhan. Diberbagai jenjang pendidikan di Jawa Tengah, macapat masih diajarkan sebagai salah satu materi ajar pada pelajaran bahasa daerah maupun seni budaya (Daryanto, 2014).

Diantara kelima golongan tembang, macapat menjadi tembang yang paling terkenal dan digemari oleh masyarakat. Isi tembang dan cengkok yang sederhana dan mudah dipelajari pada tembang macapat menjadi faktor mengapa macapat sangat digemari (Yudoyono, 1984). Tembang macapat terikat pada tiga aturan yaitu guru gatra, guru lagu, dan guru wilangan. Guru gatra yaitu banyanya baris dalam satu bait, guru lagu merupakan aturan mengenai akhir huruf vokal pada akhir baris, guru wilangan merupakan aturan mengenai banyaknya suku kata dalam satu baris. Sampai saat ini macapat merupakan salah satu bahan ajar pada jenjang pendidikan dasar dan menengah yang dikuatkan dengan SK Gubernur Jawa Tengah no.423.5/5/2010 (Daryanto et al., 2015).

Media pembelajaran yang dikembangkan memuat materi tembang macapat. Beberapa aplikasi mengenai pembelajaran tembang macapat memang sudah ada dan bisa dicari di playstore. Namun kebutuhan tembang macapat dengan bahasa yang mudah dipahami, adanya catatan notasi dan lirik, dan sesuai dengan tematik pembelajaran, masih cukup sedikit. Maka pada penelitian ini dikembangkan produk media pembelajaran tembang macapat yang sesuai dengan kebutuhan pembelajaran di sekolah dasar, karena setiap jenjang pendidikan memiliki karakteristik masing-masing dan setiap satuan pendidikan memiliki kesempatan untuk menanamkan nilai-nilai pendidikan karakter dan menerapkannya kepada peserta didik dengan inovatif dan kreatif (Sutjipto, 2011).

Pembelajaran macapat merupakan bentuk apresiasi, pelestarian, pengembangan dan pewarisan budaya nusantara. Selain itu melalui tembang macapat juga bisa memperkuat proses pendidikan karakter, karena macapat merupakan salah satu bentuk karya sastra yang bisa dimanfaatkan untuk memberikan pengajaran moral kepada anak (Wahid \& Saddhono, 2017). Pada jenjang sekolah dasar, ada materi tembang macapat yang selain diajarkan di kelas juga diadakan lomba nembang macapat tingkat sekolah. Maka selain pembekalan kemampuan teknis, penguatan nilai budaya dan karakter melalui tembang macapat penting untuk dilakukan tidak hanya bagi siswa sekolah dasar, tetapi juga bagi mahasiswa PGSD sebagai calon pendidik di sekolah dasar. Bagi mahasiswa PGSD UPGRIS, pembekalan teknis, filosofis, dan penguatan karakter melalui tembang macapat menjadi sangat penting. Tidak hanya bagi siswa yang akan diajarnya kelak, tetapi juga bermanfaat bagi diri pribadi masing-masing mahasiswa.

\section{METODE}

Penelitian ini merupakan penelitian dan pengembangan (research and development), yaitu merupakan suatu metode penelitian untuk mengembangkan, menyempurnakan atau memperbaiki produk dan praktik dalam bidang pendidikan. Produk pendidikan itu berupa buku ajar, media pembelajaran, model, strategi dan pengorganisasian pembelajaran (Soegeng, 2016).

Penelitian ini akan melaksanakan 4 dari 10 langkah penelitian dan pengembangan yang dipaparkan oleh Borg dan Gall (dalam Soegeng, 2016). Penelitian ini disesuaikan dengan proses pembelajaran yang sedang berlangsung, dikarenakan situasi pembelajaran yang dilakukan secara online, maka hanya dilakukan 4 langkah 
1587 Pengembangan Media Pembelajaran Tembang Macapat Berbasis Android Bagi Mahasiswa PGSD UPGRIS - Prasena Arisyanto, Singgih Adhi Prasetyo, Mei Fita Asri Untari, Riris Setyo Sundari

DOI : https://doi.org/10.31004/basicedu.v5i3.945

awal untuk menghasil produk awal dan diharapkan dapat diteruskan pada penelitian selanjutnya. Langkahlangkah dalam penelitian ini yaitu pertama, studi pendahuluan meliputi analisis kebutuhan dan studi pustaka. Kedua, planning (merencanakan penelitian), mencakupi merumuskan tujuan, memperkirakan anggaran dan waktu yang diperlukan. Ketiga, menentukan kualifikasi dan peran peneliti, mengembangkan rancangan mencakupi menentukan desain produk, menentukan sarana yang diperlukan, menentukan tahap pelaksanaan uji desain di lapangan, mendeskripsikan tugas personalia yang terlibat. Keempat, melakukan tes lapangan awal sebagai uji produk terbatas yang dilaksanakan hingga diperoleh desain yang layak secara substansi dan metodologi. Kelima, revisi produk utama untuk memperbaiki atau menyempurnakan desain yang bersifat internal berdasar hasil uji lapangan terbatas, dengan pendekatan kualitatif untuk mengevaluasi proses.

Teknik pengumpulan data dilakukan dengan wawancara, angket dan studi dokumen. Wawancara dilakukan kepada budayawan dan seniman macapat. Wawancara dilakukan untuk mengumpulkan data mengenai pembelajaran macapat di sekolah dasar, masyarakat, dan gambaran mengenai media pembelajaran macapat yang baik. Wawancara dilakukan secara langsung, terbuka dan terstuktur. Hasil wawancara berupa transkrip wawancara. Angket dilakukan dengan menyebarkan formulir online kepada guru di sekolah dasar. Angket digunakan untuk mengumpulkan data mengenai pembelajaran macapat di sekolah dasar, kendala yang dihadapi, dan gambaran kebutuhan media pembelajaran tembang macapat.

Studi dokumen dilakukan dengan menganalisis beberapa aplikasi sejenis yang didapatkan dari playstore dan media pembelajaran macapat sebelumnya. Ada tiga media pembelajaran yang dianalisis. Analisis dokumen menggunakan konsep media pembelajaran dengan melihat bentuk, fungsi, dan isi dari media tersebut. Studi dokumen dilakukan untuk mendapatkan rancangan draf produk media pembelajaran macapat yang akan dikembangkan sehingga memiliki keunggulan dan keunikan dari media sejenis yang sudah ada.

Analisis data dilakukan secara kualitatif dan kuantitatif. Analisis data kualitatif dilakukan pada wawancara, angket, dan studi dokumen, sedangkan analisis data kuantitatif dilakukan pada angket respon yang dilakukan pada uji draf produk. Analisis data kuantitatif dilakukan untuk mendapatkan hasil respon mengenai penerapan draf produk, dan kesesuaian aplikasi dengan pembelajaran macapat.

\section{HASIL DAN PEMBAHASAN}

Studi pendahuluan dilakukan dengan cara melakukan wawancara, studi dokumen, dan observasi. Wawancara dilakukan kepada 6 orang guru sekolah dasar dan 2 orang budayawan di Kota Semarang. Guru sekolah dasar diwawancara secara tidak langsung untuk mencari data mengenai pelaksanaan pembelajaran macapat di sekolah dasar, sedangkan budayawan diwawancara terkait dengan pembelajaran macapat di masyarakat. Studi dokumen dilakukan dengan mencari penelitian terdahulu mengenai macapat dan produk media pembelajaran macapat. Studi dokumen dilakukan dengan cara mengamati media pembelajaran macapat yang sudah ada dan aplikasi macapat yang ada di playstore.

Berdasarkan wawancara dan angket semua responden memberikan pendapat yang sama mengenai bentuk media pembelajaran macapat, yaitu harus menyesuaikan dengan perkembangan teknologi saat ini dan membuat tampilan yang menarik minat anak agar mau melihat dan belajar tembang macapat. Penggunaan teknologi bisa dalam bentuk aplikasi di gawai atau video interaktif dengan menampilkan tokoh yang disukai anak atau yang bisa menarik perhatian anak. Anak-anak zaman sekarang pada umumnya sudah terpengaruh oleh budaya modern (Susilo, 2018) salah satunya adalah teknologi gawai. Maka penggunaan gawai sangat diperlukan karena saat ini anak sudah mahir dan sering menggunakan gawai, dan gawai sudah lekat dengan kehidupan anak, maka perlu menggunakan alat yang dipahami dan sering dioperasionalkan oleh anak.

Media pembelajaran macapat telah ada dan bisa diunduh pada playstore, namun bukan berarti masalah teratasi. Ada kendala lain yang muncul yaitu anak sulit untuk memahami dikarenakan beberapa hal yaitu penggunaan bahasa yang sulit, kesulitan membaca notasi, dan keterasingan terhadap laras slendro pelog. 
1588 Pengembangan Media Pembelajaran Tembang Macapat Berbasis Android Bagi Mahasiswa PGSD UPGRIS - Prasena Arisyanto, Singgih Adhi Prasetyo, Mei Fita Asri Untari, Riris Setyo Sundari

DOI : https://doi.org/10.31004/basicedu.v5i3.945

Tembang macapat yang banyak tersedia atau dipelajari merupakan macapat yang diambil dari serat yang menggunakan bahasa jawa kuna, sedangkan sekarang bahasa jawa kuna sangat jarang sekali digunakan kecuali oleh pihak tertentu sehingga menyulitkan bagi orang yang ingin belajar macapat karena tidak paham bahasa yang digunakan. Pemilihan materi tembang macapat bagi siswa SD memang tidak mudah, untuk memaksimalkan tujuan pembelajarannya terutama pada pendidikan karakter, maka perlu pemilihan tema dan materi yang sesuai (Muljono, 2012).

Studi dokumen mengenai media pembelajaran macapat juga dilakukan pada media nembang macapat karya Widodo (Widodo, 2008). Media ini berupa buku teks berisi berbagai tembang macapat dalam berbagai laras dan pathet yang dilengkapi dengan kaset compact disk (CD) berisi rekaman suara tembang macapat tersebut. Cara menggunakannya yaitu dengan memutar kaset CD pada alat tertentu kemudian mendengarkan suara sambil melihat teks macapat yang ada dibuku, cara belajar itu dilakukan secara berulang sampai paham dan hafal. Media pembelajaran ini diciptakan pada tahun 2008, pada tahun 2008 karya seperti ini sudah sangat baik dan modern sesuai dengan perkembangan zaman dan teknologi pada saat itu. Namun seiring dengan perkembangan zaman dan teknologi yang begitu pesat, maka saat ini media pembelajaran karya Widodo ditemukan kendala dalam pemanfaatannya.

Studi dokumen juga dilakukan dengan menganlisis aplikasi tembang macapat yang tersedia pada playstore. Ada 8 aplikasi yang muncul di playstore. Secara umum aplikasi tersebut menampilkan audio dan watak tembang macapat, namun ada pula yang menambahkan menu bermain atau kuis yang bisa dikatakan sebagai pengulangan atau tes setelah belajar macapat. Dari 8 aplikasi yang ditemukan, peneliti memfokuskan pada 2 aplikasi untuk diamati lebih lanjut yaitu macapat jawa produksi Logivity dan macapat jawa produksi Ugiee. Kedua aplikasi ini dipilih dengan pertimbangan tampilan, fitur, dan isi yang lebih menarik dan baik dibanding dengan aplikasi yang lain.

Berdasarkan studi dokumen baik melalui media pembelajaran macapat yang sudah ada maupun melalui artikel jurnal dan prosiding, peneliti menyimpulkan bahwa diperlukan media yang memiliki karakteristik multimedia, interkatif, mandiri (Daryanto, 2013) dan kekinian dengan berbasis smartphone. Isi tembang macapat juga harus diperhatikan yaitu yang menggambarkan kehidupan anak atau menggunakan bahasa yang anak bisa memahami yaitu bahasa jawa ngoko, krama madya dan krama inggil. Penggunaan bahasa yang sesuai bertujuan agar pesan dari tembang macapat bisa lebih cepat dipahami (Sugimin, 2010). Memang lebih baik jika bisa menyusun sendiri teks tembangnya, namun jika kesulitan bisa mencari dari berbagai sumber buku macapat, dengan catatan tidak menggunakan bahasa yang relatif bisa dipahami oleh anak.

Berdasarkan studi pendahuluan, peneliti merumuskan gambaran awal mengenai produk yang akan disusun. Perencanaan produk dibagi menjadi 2 yaitu rencana bentuk dan rencana isi. Rencana bentuk produk yaitu akan berbasis android sehingga bisa diakses melalui gawai, menampilkan teks tembang macapat yang bisa dipahami anak. Direncanakan tidak menggunakan video untuk menghindari ukuran file yang terlalu besar, tampilan isi akan difokuskan pada audio dan teks, untuk menghindari kebosanan maka akan ditampilkan tokoh kartun atau tokoh yang dipahami oleh anak.

Rencana isi produk yaitu sejarah macapat, struktur macapat, teks tembang, rekaman suara tembang macapat, penjelasan karakter macapat dan terjemahan teks tembang, dan pengembang produk. Teks tembang akan disusun dengan bahasa yang bisa dipahami oleh anak, mengangkat tema alam dan pendidikan. Tembang macapat direncanakan akan ditampilkan 11 buah namun dengan satu laras saja, yaitu laras pelog dengan menampilkan pathet nem dan pathet barang.

Peneliti menggunakan software flash untuk menyusun aplikasi menang maca. Tahapan dalam menyusun draf aplikasi yaitu pertama membuat planboard draf aplikasi, selanjutnya membagi tugas untuk menyusun materi dan membuat desain tampilan aplikasi, kemudian menyusun menjadi sebuah aplikasi utuh. Penyusunan materi dilakukan dengan cara mencari sumber mengenai tembang macapat dan kemudian merangkum menjadi sebuah materi singkat. Materi yang disusun antara lain sejarah macapat, metrum dan 
karakter macapat, teks dan notasi macapat. Materi teori macapat yang telah disusun kemudian dilanjutkan dengan materi praktik nembang macapat. Peneliti melakukan rekaman audio 11 tembang macapat tersebut dengan menggunakan microphon recording dan melakukan penataan dengan software audacity 2020. Pada desain tampilan, peneliti awalnya membuat gambar di kertas kemudian melakukan diskusi internal. Setelah semua bagian selesai digambar, peneliti mulai membuat desainnya dengan menggunakan software adobe ilustrator.

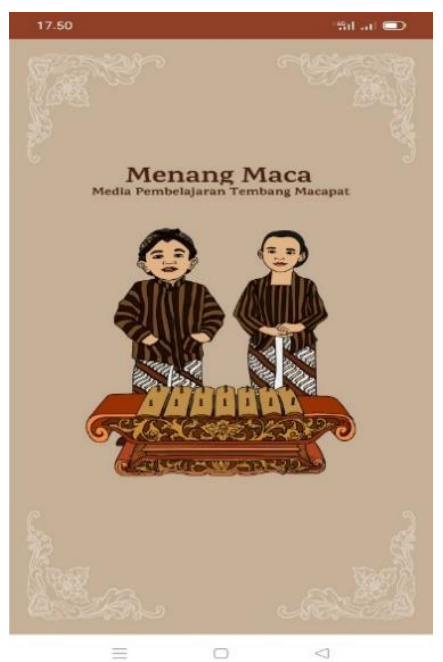

Gambar 1 cover aplikasi

Pada cover peneliti melakukan revisi dengan mengubah format tampilan dan desain cover. Pada tampilan awal menggunakan format landscape, setelah proses diskusi dengan tim, dirasa format landscape kurang menarik karena banyak sekali bagian yang terpotong sehingga harus selalu digeser. Peneliti akhirnya mengubah ke format potrait dengan maksud agar tampilan yang dilihat bisa lebih utuh tanpa perlu banyak melakukan pergeseran layar. Pengubahan format ini tentunya dilakukan pada semua isi aplikasi. Pada daftar aplikasi perubahan dilakukan pada tampilan, desain menu, dan desain grafis. Pada tampilan, format yang digunakan diubah dari landscape menjadi potrait dengan tujuan meringkas slide dan mempermudah penggunaan. Semua menu dijadikan satu tampilan sehingga pengguna lebih mudah dalam mencari menu yang dimaksud tanpa banyak sub menu.

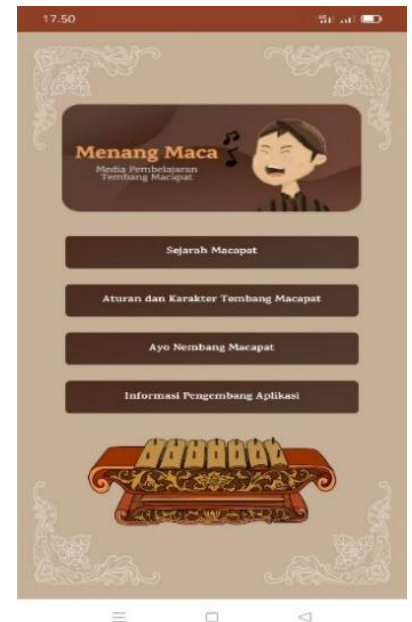

Gambar 2 menu pada aplikasi 
Pada desain menu dan desain grafis, dilakukan perubahan dengan menyusun semua menu pada satu halaman dan disusun vertikal, sehingga pengguna tidak perlu terlalu banyak melakukan pilihan pada sub menu. Berbeda dengan desain sebelumnya yang memiliki pola menu dan sub menu pada setiap pilihannya. Pada revisi yang dilakukan, beberapa halaman sub menu dipangkas, sehingga bisa lebih cepat dalam menemukan materi yang dicari. Desain grafis diperbarui dengan membuat desain yang lebih menarik menyesuaikan dengan format yang diterapkan.

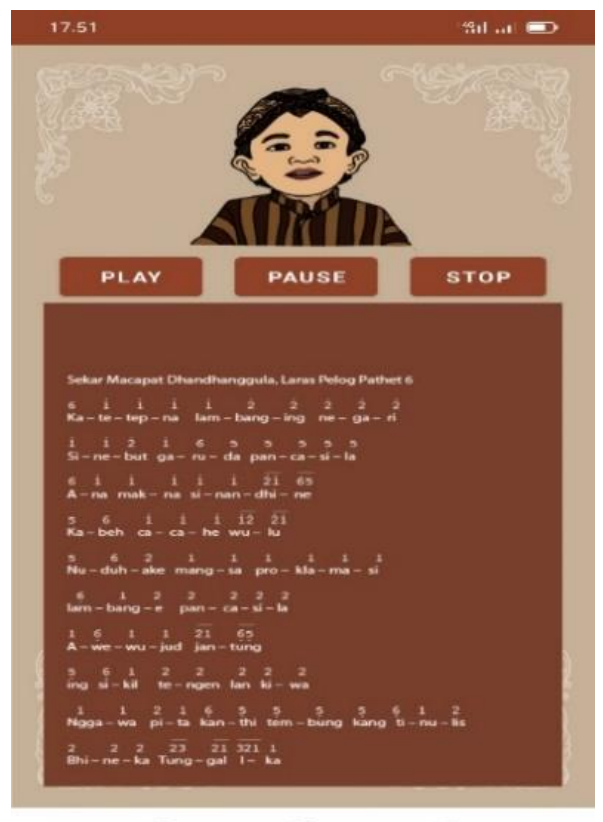

Gambar 3 isi pada menu tembang macapat

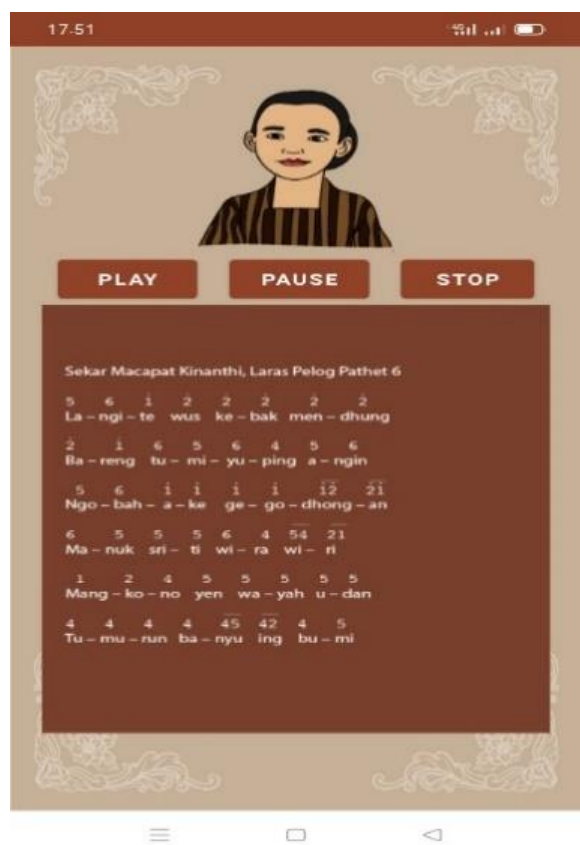

Pada bagian materi tembang macapat, peneliti melakukan perubahan pada tampilan, desain isi, dan desain grafis. Pada tampilan dilakukan perubahan dengan menerapkan format potrait dari sebelumnya menggunakan format landscape. Perubahan format dilakukan agar teks tembang macapat bisa lebih mudah dibaca tanpa harus selalu menggeser layar. Tiga pilihan bantuan diberikan pada bagian materi tembang macapat, yaitu play, pause, dan stop. Play yaitu mulai memutar rekaman suara tembang macapat, pause artinya menjeda sementara rekaman suara, dan stop artinya menghentikan pemutaran rekaman suara. Tiga bantuan ini berfungsi untuk membantu proses belajar.

Pada desain grafis, dilakukan perubahan yang menyesuaikan dengan format tampilan. Perubahan dilakukan agar tampilan aplikasi menjadi lebih menarik. Ada 2 desain grafis yang diterapkan yaitu desain yang menampilkan karakter anak laki-laki, dan desain yang menampilkan karakter anak perempuan. Desain yang menampilkan karakter anak laki-laki diterapkan pada tembang macapat Sinom, Dhandhanggula, Gambuh, Durma, Megatruh, Pocung. Desain yang menampilkan karakter anak perempuan diterapkan pada tembang macapat Mijil, Kinanthi, Asmaradana, Maskumambang, Pangkur. Pembagian desain dilakukan secara acak dengan tujuan menghasilkan tampilan yang berbeda dan variatif sehingga pengguna menjadi lebih tertarik dalam menggunakan aplikasi menang maca. Komposisi warna pada tampilan juga dibuat kontras agar teks dan notasi tembang macapat menjadi lebih terbaca dan jelas.

Pemilihan teks tembang macapat didasarkan pada tema pendidikan dan alam. Peneliti mencari referensi tembang macapat dengan tema dan bahasa yang sesuai dengan rancangan media. Teks tembang macapat yang ditampilkan didapatkan dari beberapa sumber dengan menggunakan bahasa Jawa ngoko dan krama, yang kosa katanya kurang lebih telah dipelajari pada jenjang sekolah dasar sehingga mampu dipahami isinya. 
Pemahaman bahasa yang digunakan akan sangat membantu dalam proses pemahaman isi dan pendidikan karakter yang dilakukan melalui isi tembang macapat.

Penataan pada format potrait memiliki beberapa kekurangan diantaranya ukuran isi yang lebih kecil sehingga bisa menimbulkan kesulitan membaca pada beberapa orang, apalagi jika layar smartphone yang digunakan juga kecil. Kemudian semua materi aplikasi harus ditata secara vertikal, jika ditata secara horizontal tentunya kurang sesuai dengan format tampilan. Namun kelebihannya yaitu tidak perlu terlalu banyak melakukan pergeseran layar karena hampir semua materi bisa ditampilkan dalam satu halaman utuh sehingga mempermudah pengguna. Pada sekarang ini, masyarakat juga telah banyak yang menggunakan smartphone dengan layar yang cukup lebar minimal 5,5 inchi sehingga tampilan potrait bisa dilihat dengan baik, cukup jelas, dan tidak terlalu menimbulkan kendala pada penggunaan aplikasi.

Uji draf produk dilakukan kepada 10 orang yang mewakili dari tiap kelas. Uji draf produk dilakukan setelah materi tembang macapat selesai disampaikan, dengan cara mengisi link google form. Berdasarkan hasil uji draf produk dapat disimpulkan bahwa draf aplikasi menang maca dapat digunakan pada mata kuliah pendidikan seni musik pada materi tembang macapat. Berdasarkan hasil uji draf produk, beberapa hal yang menjadi catatan perbaikan adalah tampilan aplikasi dan pemahaman materi. Tampilan aplikasi dirasa masih bisa dimaksimalkan pada ukuran teks dan notasi sehingga menjadi lebih jelas jika terbaca, walaupun tampilan yang ada dalam aplikasi sudah bisa terbaca dengan baik. Pada aspek pemahaman materi, disampaikan bahwa walaupun sudah ada aplikasi pembelajaran tembang macapat yang bisa membantu mahasiswa dalam belajar tembang macapat, dan aplikasi menang maca dapat digunakan pada situasi pembelajaran online, tetapi masih diperlukan bimbingan langsung dari dosen atau guru sehingga proses dan hasil yang diharapkan bisa lebih maksimal.

Tentu belajar mandiri melalui aplikasi mempunyai kelebihan dan kekurangan. Namun aplikasi menang maca telah dapat digunakan dalam pembelajaran mandiri dan pembelajaran online, daripada tidak ada media pembelajaran yang bisa dimanfaatkan. Aplikasi menang maca tidak bertujuan untuk menggantikan peran guru, namun membantu guru dalam mengajar dan mendukung kelancaran dan kesuksesan pelaksanaan pembelajaran online, selain itu aplikasi menang maca dapat digunakan untuk belajar secara mandiri. Memanfaatkan IPTEK secara tepat akan meningkatkan kualitas seni pertunjukan yang pada akhirnya meningkatkan apresiasi masyarakat (Maryono, 2009). Senada dengan pendapat tersebut, pembelajaran tembang macapat perlu memanfaatkan kemajuan teknologi agar bisa menyesuaikan dengan perkembangan zaman, apalagi pada kondisi pandemi covid-19 saat ini. Beberapa tujuan bisa tercapai seperti pelestarian, pengembangan, dan pendidikan seni. Pada akhirnya diharapkan bahwa apresiasi terhadap tembang macapat bisa kembali meningkat dan tembang macapat bisa kembali dikenal, digemari, dan dipelajari oleh masyarakat.

\section{KESIMPULAN}

Aplikasi menang maca pada tahap draf awal, telah diujicoba pada perkuliahan seni musik pada materi tembang macapat di Program Studi Pendidikan Guru Sekolah Dasar, Universitas PGRI Semarang, dan mendapat respon yang positif. Penyusunan aplikasi Menang Maca telah menyesuaikan dengan pembelajaran di sekolah dasar, sehingga mahasiswa sebagai calon guru maupun guru di sekolah dasar dapat menggunakan aplikasi menang maca untuk pembelajaran di kelas. Draf awal aplikasi menang maca memang masih mempunyai kekurangan dan membutuhkan penyempurnaan produk, namun telah siap untuk digunakan untuk uji coba tahap awal pada skala kecil di sekolah dasar.

\section{DAFTAR PUSTAKA}

Daryanto. (2013). Media Pembelajaran Peranannya Sangat Penting dalam Mencapai Tujuan Pembelajaran. 
1592 Pengembangan Media Pembelajaran Tembang Macapat Berbasis Android Bagi Mahasiswa PGSD UPGRIS - Prasena Arisyanto, Singgih Adhi Prasetyo, Mei Fita Asri Untari, Riris Setyo Sundari

DOI : https://doi.org/10.31004/basicedu.v5i3.945

Yogyakarta: Gava Media.

Daryanto, J. (2014). Pengembangan Media Pembelajaran Tembang Macapat berformat Video Interaktif untuk Penguatan Pendidikan Karakter. Seminar Nasional Pengembangan Sumber Daya Manusia Melalui Seni Dan Pendidikan Seni, Universitas Negeri Semarang.

Daryanto, J., Karsono, \& Matsuri. (2015). Pengembangan Media Pembelajaran Tembang Macapat Berbasis Video Interaktif. Jurnal Pendidikan Dasar Universitas Sebelas Maret, 3(2), 59-65.

Maryono. (2009). Mengparesiasi Seni dalam Konteks IPTEK. Greget, 8(2), 228-239.

Muljono, U. (2012). Pendidikan Nilai Luhur Melalui Tembang (Lagu) Dolanan Anak. Selonding, 1(1), 100112. https://doi.org/10.24821/selonding.v1i1.67

Pratiwi, S. I., \& Wahyudi, W. (2021). Pengembangan Bahan Ajar Tematik Berbasis Website untuk Peserta Didik di Sekolah Dasar. Edukatif, 3(2), 333-340.

Prihantono, D. (2019). Macapat Seni Adiluhung Kabudayan Jawi. Sleman: Javalitera.

Soegeng, A. . (2016). Metode Penelitian. Yogyakarta: Magnum Pustaka Utama.

Sugimin. (2010). Perkembangan Macapat dan Fungsinya dalam Karawitan Jawa.pdf. Gelar, 8(2), 248-264.

Susilo, Y. (2018). Pembelajaran Tembang Dolanan Untuk Melestarikan Bahasa Ibu Mengandung Ajaran Budi Pekerti. Seminar Nasional Bahasa, Sastra Daerah, Dan Pembelajarannya (SN-BSDP) Program Studi Pendidikan Bahasa Dan Sastra Daerah FPBS - Universitas PGRI Semarang Di Semarang, Jawa Tengah $21 \quad$ Februari $2018, \quad$ 441-448. http://prosiding.upgris.ac.id/index.php/pbsd18/pbsd2018/paper/view/2421

Sutjipto. (2011). Rintisan Pengembangan Pendidikan Karakter di Satuan Pendidikan. Jurnal Pendidikan Dan Kebudayaan, 17(5), 501. https://doi.org/10.24832/jpnk.v17i5.45

Syamsurijal, \& Sarwan. (2021). Kondisi Psikologis Mahasisawa PGSD Universitas Muhammadiyah Buton ( UMB ) dalam Pelaksanaan Pembelajaran Daring di Masa Pandemi. Edukatif, 3(1), 220-226.

Wahid, A. N., \& Saddhono, K. (2017). Ajaran Moral Dalam Lirik Lagu Dolanan Anak. Mudra, 32(2), 172177. https://doi.org/10.31091/mudra.v32i2.107

Widodo. (2008). Macapat: Teori dan Praktik Nembang. Semarang: Unnes Press.

Widodo. (2010). Lelagon Dolanan Anak Dan Pendidikan Karakter. Harmonia, 10(2), 1-16. https://doi.org/10.15294/harmonia.v10i2.62

Yudoyono, B. (1984). Gamelan Jawa Awal Mula, Makna, Masa Depannya. Jakarta: Karya Unipress. 